\title{
Bioactive compounds and chemical composition of Brazilian Cerrado fruits' wastes: pequi almonds, murici, and sweet passionfruit seeds
}

\author{
Ana Cristina Moreira Andrade ARAÚJO ${ }^{1}$, Evandro Galvão Tavares MENEZES ${ }^{1}$, André William Costa TERRA ${ }^{1}$, \\ Bruna Oliveira DIAS ${ }^{1}$, Érica Resende de OLIVEIRA ${ }^{1 \star}$, Fabiana QUEIROZ ${ }^{1}$
}

\begin{abstract}
Pequi, murici and sweet passionfruit are typical fruits from Brazilian Cerrado, which stand out for their sensory attributes such as color, flavor and aroma, in addition to their high nutritional value. Their seeds are by-products from the industrial processing of juices, pulps, jellies, and others, and have great exploitation potential due to their high oil content and the presence of bioactive compounds. The present work aimed to evaluate the chemical composition of pequi almonds, and of murici and sweet passionfruit seeds, and also to quantify the total phenolic compounds, carotenoids, anthocyanins and antioxidant activity by the scavenging activity of $\bullet$ DPPH method. Concerning the chemical composition, pequi almonds presented the highest concentration of lipids (50\%), followed by sweet passionfruit (30\%) and murici seeds (15\%). The almonds from pequi fruit showed the greatest content of protein $(33.3 \%)$ followed by sweet passionfruit seeds (15\%), which presented the highest amount of fiber (41.3\%). Murici seeds exhibited the highest content of carbohydrates (46.4\%). Pequi almonds had the greatest content of the following minerals, potassium, magnesium, sulfur, manganese, zinc, copper, iron, and sodium, and anthocyanins (14.4 $\mathrm{mg}$ CYG/100 g d.b.). Sweet passionfruit seeds presented the greatest amount of calcium, and also had the highest carotenoid content $(9 \mathrm{mg} / 100 \mathrm{~g}$ d.b.). Murici seeds showed the highest potential for bioactive compounds, with $404 \mathrm{mg}$ GAE/100 g d.b. and $81 \%$ of scavenging activity for the $\bullet$ DPPH. The results demonstrated that the studied seeds have the potential to be sources for new product development, such as oil.
\end{abstract}

Keywords: bioactive compounds; antioxidants; polyphenols; anthocyanins; nutritional composition.

Practical Application: Fruit seeds from the Brazilian bioma, Cerrado, are of great nutritive content and could be reinserted into the industrial process and add value to these material and to the industry itself. Pequi almonds presented the highest concentration of lipids, also of minerals and anthocyanins, and great content of protein; sweet passionfruit seeds presented the highest amount of fiber and carotenoids; murici seeds showed the highest content of carbohydrates and the best potential for bioactive compounds, including the content of polyphenols and antioxidant activity.

\section{Introduction}

Cerrado is a vegetation known as the Brazilian savanna. It has great relevance in the Brazilian scenario, constituting the second largest vegetation of the country, occupying around $22 \%$ of the national territory (Carrazza \& Ávila, 2010; Ratter et al., 1997). It is a rich and globally distinguished biome due to its extension, ecological diversity, carbon reserves, and hydrological role in the South-American continent, besides its social-cultural diversity (Carrazza \& Ávila, 2010). The fruit species found in this vegetation have great agricultural and technological potential, and are endowed with high nutritional value, besides having very singular characteristics, such as the attributes of color, flavor, and aroma (Almeida, 1998; Almeida \& Silva, 1994; Souza et al., 2012).

Pequi fruit (Caryocar brasiliense Camb) is a very typical fruit found in Cerrado that shows great economic potential. It is widely used in cooking, has therapeutic properties, in addition to being a source of oil (Almeida \& Silva, 1994), which can be applied in the food and cosmetic industries. It has a drupe with light green bark, it has a spiky endocarp, and both pulp and almond adhered to the core are edible (Ratter et al., 1997). Each fruit has one to four almonds enveloped by a yellow, white or pinkish flesh. Pequi pulp and almond are rich in riboflavin, thiamine, provitamin $\mathrm{A}$, and in oil, attributing high nutritional value to these edible fractions (Oliveira et al., 2006; Torres et al., 2016). In addition, Roesler et al. (2010) stated that pequi represents a viable source of natural antioxidant, due to its high free radical neutralization capacity.

According to studies carried out by Almeida (1998), Vilas Boas (2004), and Lima et al. (2007), pequi has relevant values of certain components, when compared to other native species. According to these authors, the protein content found in pequi almonds is inferior only to jatobá seeds (Hymenaea stigonocarpa Mart.) (9\% d.b.) (Matuda \& Maria Netto, 2005), and baru almonds (Dipteryx alata Vog.) (23.8-28.2\% d.b.) (Fernandes et al., 2010). The lipid content presented by the pequi pulp and almond are worthy of note, given that they are the greatest when compared to other species, and overcome the content present in avocado 
pulp (Persea Americana Mill.) (Hass variety) (15.8\%) (RodríguezCarpena et al., 2011), açaí (Euterpe oleracea Mart.) (49.4\% d.b.) (Neida \& Elba, 2007), and buriti (Mauritia flexuosa) (19\% w.b.) (Darnet et al., 2011).

Another fruit from Cerrado is murici (Byrsonima crassifolia), which belongs to the Malpighiaceae family, and has a peculiar aroma and flavor. Rezende \& Fraga (2003), and Alves \& Franco (2003) resembled the strong odor that the fruit has to that of a rancid cheese. The murici grows in small trees of up to $5 \mathrm{~m}$ of height called muricizeiros. Ripe fruits are yellowish and have a diameter of 1 to $2 \mathrm{~cm}$, and contain one hard and woody seed, which after milled releases an aroma alike to its pulp's, and both odour are suchlike the aroma from pequi almond oil, with a cheesy-like odour due to the presence of butyric acid in their composition. Abadio Finco et al. (2012) studied few Cerrado species, such as cagaita (Eugenia dysenterica), buriti (Mauricia flexuosa), and murici, and observed that murici had the greatest content of phenolic compounds. According to Guimarães \& Silva (2008), it is important to develop different processing techniques so that the use of murici is diffused and that a higher value is added to this fruit.

Brazil has about 120 native species of the genus Passiflora. Fifty of them can be found in Cerrado, among which, Passiflora cincinnata, P. alata, P. setacea, and P. nitida, are better known (Oliveira \& Ruggiero, 2005). Passiflora alata stands out for the pleasant and sweet aroma of the pulp, being appreciated for in natura consumption. It is popularly known as sweet passionfruit (Braga et al., 2006). Passionfruit seeds are one of the greatest wastes produced by the industry, and have been shown to be valuable to the food industry due to their high fiber, protein, and oil content (Oliveira et al., 2013).

The Brazilian Cerrado has a wide variety of plants that have significant relevance to be applied in the cosmetic, pharmaceutical, and food industries, being sources of compounds of high biotechnological interest (Caramori et al., 2004). They are sources of compounds with functional properties that present health benefits, so it is of great relevance to have a more detailed study about these fruits in order to new products be developed (Siqueira et al., 2013).
Nevertheless, besides their great economic and nutritional potential (Santana \& Naves, 2003), very few industrialized products can be found available in the market, and intensive extractivism may even produce genetic material losses since high quality fruits, originally from higher genotypes, are collected and commercialized (Melo et al., 2004). To start a process of rational economic exploitation of native fructiferous species of Cerrado, it is necessary to have knowledge about their characteristics and interaction with the environment. However, there is very limited available information on the chemical composition and potential of these fruits, mainly concerning their seeds and edible almonds, and existent data are scattered or do not follow scientific criteria (Mariano da Silva et al., 2009).

This work aimed to evaluate the chemical composition, and bioactive compounds (carotenoids, antioxidants and phenolic) present in pequi almonds, and in the seeds of murici and sweet passionfruit in order to increase the knowledge about these fruits' wastes, and wealth the possibility of their application in new products with high added value.

\section{Materials and methods}

\subsection{Samples}

The fruits from Cerrado, pequi, murici, and sweet passionfruit were obtained from local cooperatives in Lavras, Minas Gerais, Brazil (Figure 1). The fruits were manually selected, washed with neutral detergent and tap water, and sanitized. To obtain the almonds and seeds, the fruits were pulped manually. In the case of murici, the fruit was pulped by scraping with a knife, allowing the entire seed to be obtained. Pequi fruit was split in half using a knife and hammer, and the almonds were removed with spatulas. The seeds of sweet passionfruit were separated from the pulp with the aid of a sieve. The seeds were stored in a freezer under $-18^{\circ} \mathrm{C}$, until use. Prior to analysis the raw material was vacuum dried at $45^{\circ} \mathrm{C}(48 \mathrm{~h})($ absolute pressure $=16.8 \mathrm{kPa})$ (Tecnal, TE-395, Piracicaba, Brazil), this being the time needed for the samples to reach constant weight. Afterwards, the seeds were milled (Marconi, MA048, Piracicaba, Brazil) and stored in sealed flasks inside desiccators in order not to absorb moisture.
(A)

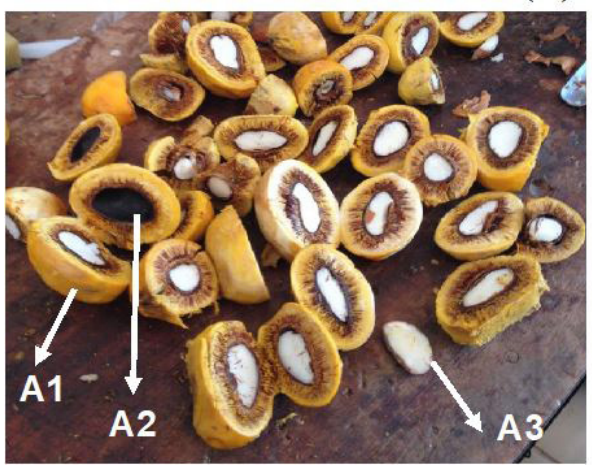

(B)

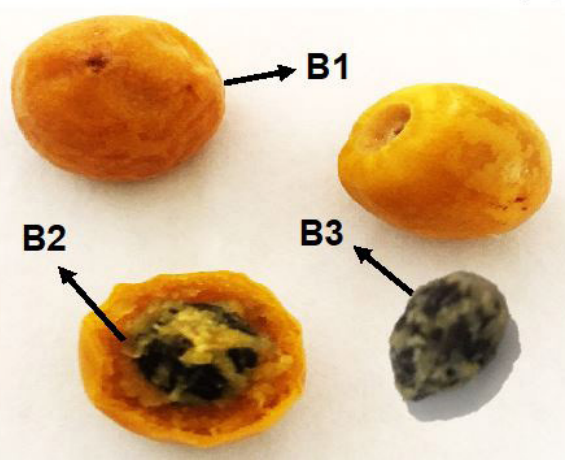

(C)

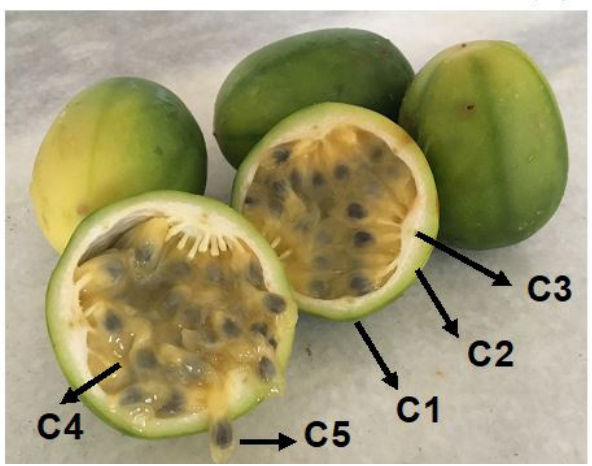

Figure 1. Pequi seeds (A), murici fruits (B), and sweet passionfruits (C). (A1): Edible internal mesocarp (yellow pulp); (A2): Thorny endocarp containing the edible almond; (A3): Edible almond. (B1): Epicarp; (B2): Edible mesocarp (pulp); (B3): Endocarp (seed). (C1): Epicarp; (C2): Mesocarp; (C3): Aryl; (C4): Edible endocarp (pulp); (C5): Seed. 


\subsection{Chemical analyzes}

\section{Proximate composition}

Moisture content, ashes, proteins, lipids, and total fibers were determined according with the official methods of analysis of the Association of Official Analytical Chemists (2016). The carbohydrate fraction was determined by the difference method (100 - \%lipids - \%protein - \%fiber - \%ashes), values in dry basis (d.b.). For conversion of the total nitrogen content of the protein, factor 6.25 was used (Food and Agriculture Organization of the United Nations, 2003). The total energetic value of the material was calculated using the conversion factors of $4 \mathrm{kcal} / \mathrm{g}$ for protein and carbohydrate, and $9 \mathrm{kcal} / \mathrm{g}$ for lipids (Merril \& Watt, 1973).

Starch

Starch content was determined according to Somogyi's method adapted by Nelson (1944). The results were expressed as $\mathrm{g} / 100 \mathrm{~g}$ of sample in dry basis (d.b.).

\section{Pectic substances}

Total and soluble pectin were extracted according to the technique described by McCready \& McComb (1952) and determined according to Bitter \& Muir (1962).

\section{Minerals}

Minerals (phosphorus, potassium, calcium, magnesium, sulfur, sodium, manganese, zinc, iron, and copper) were evaluated according to the methodology described by Salinas \& Garcia (1985).

\subsection{Bioactive compounds}

\section{Carotenoids}

The extraction and quantification of total carotenoids were performed according to the methodology proposed by (Carvalho et al., 2012). The content of carotenoids in $\mu \mathrm{g} / \mathrm{g}$ was estimated according to Equation 1.

Carotenoids $=\frac{A b s \times v \times 10^{6}}{100 \times E_{1 c m}^{1 \%} \times m}$

Abs = absorbance $(\mathrm{nm})$;

$\mathrm{v}=$ total extract volume $(\mathrm{mL})$;

$\mathrm{m}=$ sample $(\mathrm{g})$;

$E_{l c m}^{1 \%}=2592($ Extinction coefficient for $\beta$-carotene in petroleum ether).

\section{Total phenolics and antioxidant assay}

\section{Extraction}

The extracts were obtained by the method described by Brand-Williams et al. (1995).
Total phenolics determination

Total polyphenols content was quantified using the FolinCiocalteu colorimetric method (Waterhouse, 2002).

In vitro antioxidant activity

The method used is based on the extinction of the absorption of 2,2-diphenyl-1-picrylhydrazyl free radical $(\bullet \mathrm{DPPH})$, and it was proposed by Brand-Williams et al. (1995). Results were expressed as inhibition percentage of free radical scavenging oxidation (IP) according to Equation 2.

$I P(\%)=100-\left[\frac{\left(A b s_{\text {control }}-A b s_{\text {sample }}\right)}{A b s_{\text {control }}}\right] \times 100$

\section{Monomeric anthocyanins}

The differential $\mathrm{pH}$ methodology proposed by Wrolstad (1993) was used to determine the total monomeric anthocyanin content. The amount of total monomeric anthocyanins (TMA), expressed in terms of cyanidin-3-glucoside (CYG) (mg CYG/ 100g sample d.b.), was calculated using Equations 3 and 4.

$A=\left(A_{510}-A_{700}\right)_{p H 1,0}-\left(A_{510}-A_{700}\right)_{p H 4,5}$

$T M A=(A \times M W \times D F \times V e \times 1000) /(\varepsilon \times 1 \times M)$

MW = Molar weight of cyanidin-3-glucoside (449 g/mol);

$\mathrm{DF}=$ Dilution factor;

$\mathrm{V}=$ Extract volume $(\mathrm{mL})$;

$\varepsilon=$ Molar extinction coefficient of cyanidin-3-glucoside (29600);

$\mathrm{M}=$ sample mass $(\mathrm{g})$.

\subsection{Statistical analysis}

Analysis of variance and Tukey's mean comparison test ( $\mathrm{p}<5 \%$ ) were used to compare the data, which are normally distributed. STATISTICA software version 8.0 (StatSoft, Inc., 2007) was used to carry out the statistical analyzes.

\section{Results and discussion}

\subsection{Proximate composition}

The proximate composition expresses, in general, the nutritive value of food and corresponds to the proportion of homogeneous groups of substances present in $100 \mathrm{~g}$ of the considered food. The groups of substances considered to be homogeneous are those that are present in all foods, namely, moisture, lipid, protein, fiber, ash, and carbohydrates (Moreno Luzia \& Jorge, 2011).

Table 1 shows the proximal composition and the energy values of the pequi almonds, murici, and sweet passionfruit seeds obtained in this study. Dry matter of pequi almonds is mainly composed of lipids and protein. Being fiber, ashes, and carbohydrates the minor components. Murici is mainly composed by lipids and carbohydrates, mostly consisting of dietary fibers. Sweet passionfruit presented the highest content 
Table 1. Nutritional value (\% of dry matter) of pequi almonds, murici and sweet passionfruit seeds.

\begin{tabular}{lccc}
\hline Macronutrients (g/100 g) & Pequi & Murici & $\begin{array}{c}\text { Sweet } \\
\text { passionfruit }\end{array}$ \\
\hline Lipid & $50 \pm 0.7^{\mathrm{a}}$ & $15 \pm 1.8^{\mathrm{c}}$ & $29.6 \pm 1.5^{\mathrm{b}}$ \\
Protein & $33.3 \pm 0.5^{\mathrm{a}}$ & $8.8 \pm 0.7^{\mathrm{c}}$ & $15 \pm 1.4^{\mathrm{b}}$ \\
Ash & $5.8 \pm 0.3^{\mathrm{a}}$ & $2.2 \pm 0.2^{\mathrm{b}}$ & $1.4 \pm 0.3^{\mathrm{c}}$ \\
Fiber & $5 \pm 1.5^{\mathrm{c}}$ & $27.5 \pm 0.6^{\mathrm{b}}$ & $41.3 \pm 2.2^{\mathrm{a}}$ \\
Carbohydrates & $5.7 \pm 2^{\mathrm{c}}$ & $46.4 \pm 1.8^{\mathrm{a}}$ & $12.7 \pm 2.3^{\mathrm{b}}$ \\
Energetic value $(\mathrm{kcal} / \mathrm{kg})$ & 606.2 & 356.8 & 377.2 \\
\hline
\end{tabular}

Data are mean \pm standard deviation $(n=3)$; ${ }^{\text {a-c }}$ Data followed by the same letter in a row do not differ statistically $(\mathrm{p}<0.05)$.

of fibers, followed by the lipid and protein fractions. Concerning the water fraction, all materials presented different moisture content $(\mathrm{p}<0.05)$. Pequi almonds presented the greatest content of moisture (36\% w.b.), followed by murici $(26.4 \%$ w.b.), and sweet passionfruit seeds (12\% w.b.).

Pequi dried almond presented elevated energy value. This trend was already expected considering that pequi almonds presented higher lipid content. Lima et al. (2007) found similar caloric value for pequi kernel (598 kcal/100 g). It is possible to affirm that pequi almond is rich in lipids. It has higher oil content than its own pulp, which according to Oliveira et al. (2006), who studied the nutritional value of pequi in different maturity stages, contains about $27 \mathrm{~g} / 100 \mathrm{~g}$ of lipids for ripe fruits. This result indicates that pequi almond is a good source of oil when compared to soy beans, for instance, which contain an average of $20 \mathrm{~g} / 100 \mathrm{~g}$ of lipids (Gunstone, 2005). There are few studies showing success in applying pequi pulp oil in the cosmetic and pharmaceutic industries, due to its clearness, soft aroma, and high absorbitivity by human skin (Oliveira et al., 2010), which is and indicator that the almond oil might be a promissing input to those industries too, as well as to the food field. Lima et al. (2007) reported that about $52 \mathrm{~g} / 100 \mathrm{~g}$ of the lipid fraction of pequi almond is constituted by fatty acids, mainly palmitc and oleic. This fatty acid composition gives the pequi almond lipid fraction great nutritional value because oleic acid consumption is related to the decrease in LDL-cholesterol (low-density lipoprotein), and in consequence, to the reduction of coronary disease risk (Ramadan et al., 2012). According to in vivo studies, the consumption of pequi pulp oil can improve the antioxidant defense system (Colombo et al., 2015), and shows hypolipidemic effects, decreasing oxidative stress and inflammatory processes (Figueiredo et al., 2016).

Pequi almond is also an important source of protein (Table 1), providing about $133.24 \mathrm{kcal}$ in each $100 \mathrm{~g}$ of material, which corresponds to $6.7 \%$ of the caloric needs of an adult with a diet of $2000 \mathrm{kcal}$ and over $40 \%$ of the daily protein intake needs for each $\mathrm{kg}$ of an adult (National Research Counsil, 1989). This shows that consumption of pequi almond may bring benefits to the health of the population, in view of the knowledge that regular consumption of protein and healthy fatty acids in the diet is related to the reduction of the risk of several pathological conditions. The proximal composition reported for pequi almond from the Northeastern region of
Brazil (Piauí) by Lima et al. (2007) is in accordance with the results of this study for the lipid fraction. The authors reported $51.5 \mathrm{~g} / 100 \mathrm{~g}$ for this component. However, they found lower content of protein $(25.3 \mathrm{~g} / 100 \mathrm{~g})$, fiber $(2.2 \mathrm{~g} / 100 \mathrm{~g})$, and ashes $(4 \mathrm{~g} / 100 \mathrm{~g})$, and higher value for carbohydrates $(8.3 \mathrm{~g} / 100 \mathrm{~g})$. Oliveira Sousa et al. (2011) also observed, as in this study, an average of $50 \mathrm{~g} / 100 \mathrm{~g}$ of total lipids, $29.7 \mathrm{~g} / 100 \mathrm{~g}$ of protein, and $4.5 \mathrm{~g} / 100 \mathrm{~g}$ of ashes in pequi almonds from different areas of the Brazilian Cerrado; yet they found higher values of fiber $(10.4 \mathrm{~g} / 100 \mathrm{~g})$ and moisture $(5 \mathrm{~g} / 100 \mathrm{~g})$, and a very low content of carbohydrates $(0.4 \mathrm{~g} / 100 \mathrm{~g})$ in contrast to the value found in this work $(2.3 \mathrm{~g} / 100 \mathrm{~g})$. These differences may be likely because the seeds come from different fruit varieties and locations.

A much lower value than the observed in this study for moisture content was observed by Araújo et al. (2009) by investigating the biometric characteristics of murici seeds from the Northeastern area of Brazil (Maceió) (7.3\%), they also observed that the seeds present a recalcitrant behavior, which according to Roberts (1973) is basically, the intolerance to dissication, to longevity, and to low temperatures. The lipid content observed in this study for murici seeds was lower than the values reported in the literature by Costa et al. (2013), $33 \mathrm{~g} / 100 \mathrm{~g}$, who analyzed the storage compounds of the seeds through cytochemical investigation. Rodrigues et al. (2016) profiled the fatty acids of murici and reported that palmitic, oleic, and linoleic acids were responsible for $95 \%$ of the total of fatty acids in murici from Belém (Pará), Brazil. However, the lipid content of $15 \mathrm{~g} / 100 \mathrm{~g}$ found here is three times higher than the amount reported by Lima et al. (2006) in their work, $5.5 \mathrm{~g} / 100 \mathrm{~g}$, showing a wide variation range of the lipid fraction in murici seeds. The protein fraction found for murici seeds in this study was $62.4 \%$ higher than the content obtained by Costa et al. (2013). These seeds have very low content of minerals, as their ashes content was very low; however, they showed the highest amount of carbohydrates, among pequi almonds, and sweet passionfruit seeds. Murici seeds presented great fiber content, higher than in its pulp (2 g/100 g) (Monteiro et al., 2015). It can be considered as a source of this nutrient, which is a very attractive feature for a nourishing material, once dietary fiber is being, especially nowadays, looked for to be inserted in diets in the healthiest way as possible. Santana et al. (2015) found $32.4 \mathrm{~g} / 100 \mathrm{~g}$ of lipid fraction in passionfruit seeds (Passiflora setacea), and Silva \& Jorge (2014) extracted $24 \mathrm{~g} / 100 \mathrm{~g}$ of oil from the seeds of yellow passionfruit (Passiflora adulis Sims). These values are in the same range of the content found in this study for the lipid fraction (29.6 g/100 g), which can still be considered high, and allows to classify the sweet passionfruit seeds as a source of oil. Sweet passionfruit seeds presented the lowest ash content. It is known that the ash content indicates the amount of minerals the sample has; amongst the seeds studied, sweet passionfruit was the less relevant source of these compounds. Regarding the amount of carbohydrates present in the seeds, passionfruit presented an intermediate content $(11.5 \mathrm{~g} / 100 \mathrm{~g})$. The macronutrient that stood out for sweet passionfruit seeds was the dietary fiber $(41.2 \mathrm{~g} / 100 \mathrm{~g})$, showing that this by-product has great potential to be reinserted in the food industry approach. Once, dietary fibers promotes physiological beneficial effects to the human organism. They assist in the digestion process, and also in the reduction of 
plasmatic cholesterol (Cavalcanti, 1989; Mattos \& Martins, 2000). They may also act in the prevention of cancer and support the control of diabetes mellitus (Kelsay, 1978). The content of fiber observed in this study for passionfruit seeds are in agreement with the results reported by Oliveira et al. (2013) (46.5\% d.b.), who studied yellow passionfruit (Passiflora edulisf. flavicarpa) seeds.

The results concerning the proximal composition of pequi almonds, and sweet passionfruit, and murici seeds indicate that pequi almond and sweet passionfruit seeds stood out due to their high lipid fraction; pequi almonds by the expressive content of protein, while sweet passionfruit seeds, by the high fiber and protein content. Murici seeds were a relevant source of carbohydrates, fibers, and lipids.

It is known that the main storage substances in the seeds are carbohydrates, lipids, and proteins. The fact that lower carbohydrate content was found in pequi almonds and sweet passionfruit seeds compared to the murici seeds may be directly related to the higher content of lipids and proteins in pequi, and lipid and fibers in the seeds of sweet passionfruit, indicating the relevance of the lipids as storage substances in these two seeds.

Varied results related to chemical composition are found for the same fruit in a range of works, what can be explained by the influence of genetic factors, method of analyzes carried out, ecological factors, and post-harvest changes resulting from physiological activity, fertility of the soil, stage of maturation, and places of cultivation (Chitarra \& Chitarra, 2005). In addition, other factors that can alter the chemical composition of fruits, are the variety, cultivar, climatic and geographic conditions of production, processing, and storage (Yu et al., 2002).

\subsection{Starch and pectic substances}

Starch and pectic substances content obtained for pequi almonds, murici, and passionfruit seeds are available in Table 2.

The content obtained in pequi almonds and murici seeds for total pectin and soluble pectin were lower than those found in sweet passionfruit seeds. On the other hand, murici seeds presented the greatest content of starch, four times higher than in pequi almonds, and thrice higher than in sweet passionfruit seeds. Souza et al. (2012) found $8.9 \%$ of starch in murici pulp.

The pectins in fruits are in different forms, characterized by different solubilities. Protopectin is a water-insoluble form which, by partial hydrolysis, produces pectinic acids or pectic acids also called soluble pectins (Baker, 1997). Almeida (1998) considers that the pequi fruit stands out because of its high pectin content, an important parameter for fruits industrialization and

Table 2. Starch, total, and soluble pectin content in paqui almonds, in murici, and sweet passionfruit seeds (dry basis).

\begin{tabular}{lccc}
\hline \multicolumn{1}{c}{ Component } & Pequi & Murici & $\begin{array}{c}\text { Sweet } \\
\text { passionfruit }\end{array}$ \\
\hline Starch (g/100 g) & $3 \pm 0.2^{\mathrm{b}}$ & $12 \pm 0.4^{\mathrm{a}}$ & $4 \pm 0.4^{\mathrm{b}}$ \\
Total pectin (mg GA/100 g) & $87 \pm 13^{\mathrm{c}}$ & $712 \pm 10^{\mathrm{b}}$ & $2135 \pm 2^{\mathrm{a}}$ \\
Soluble pectin (mg GA/100 g) & $64 \pm 8^{\mathrm{c}}$ & $81 \pm 5^{\mathrm{b}}$ & $436 \pm 2^{\mathrm{a}}$ \\
\hline
\end{tabular}

Data are mean \pm standard deviation $(n=3)$; ${ }^{\text {a-c }}$ Data followed by the same letter in a row do not differ statistically $(\mathrm{p}<0.05)$; GA: Galacturonic acid. commercialization. According to the author, the pequi pulp contains approximately $2.3 \%$ of pectin, while other species such as buriti (Mauritia flexuosa), cagaita (Eugenia dysenterica), and mangaba (Hancornia speciosa) contain values under $1 \%$. The authors compared the content found with those present in other fruits which are also used in Brazilian diets and verified that these values are almost equivalent to those present in oranges $(\sim 2.4 \%)$.

\subsection{Mineral profile}

Table 3 shows the results for quantitative determination of some minor and trace mineral elements, and their respective Dietary Recommended Ingestion (DRI) (Scientific Committee on Food, 2006; World Health Organization, 2012), present in the seeds analyzed.

Pequi almonds presented higher concentration of all the minerals when compared to murici and sweet passionfruit seeds; except for the mineral $\mathrm{Ca}$, that presented values close to that of sweet passionfruit seeds. Murici seeds showed P, Fe, and $\mathrm{Na}$ values higher than the values found for sweet passionfruit seeds. The results of the mineral profile present in pequi almonds were also higher for $\mathrm{P}, \mathrm{Mg}, \mathrm{Na}$, and $\mathrm{Ca}$. Oliveira Sousa et al. (2011) quantified the minerals present in pequi almonds, reporting $90 \mathrm{mg} \mathrm{Ca} / 100 \mathrm{~g}, 840 \mathrm{mg} \mathrm{K} / 100 \mathrm{~g}, 5 \mathrm{mg} \mathrm{Na} / 100 \mathrm{~g}$, $450 \mathrm{mg} \mathrm{Mg} / 100 \mathrm{~g}, 22.8 \mathrm{ppm} \mathrm{Fe} / 100 \mathrm{~g}$, and $73.8 \mathrm{ppm} \mathrm{Zn/100} \mathrm{g.}$ Pequi almonds have great content of minerals as its own pulp, in which content of $\mathrm{Zn}, \mathrm{Cu}, \mathrm{Ca}, \mathrm{K}, \mathrm{Mg}$, and $\mathrm{P}$ are higher than those of almost all fruits traditionally cultivated and consumed by Brazilian population (Universidade Estadual de Campinas, 2011). Concerning the macrominerals, $P$ was the one found in greater content, $\mathrm{K}$ also distinguished by its elevated content, followed by $\mathrm{Ca}$, and $\mathrm{Mg}$.

Concerning the microminerals, the most relevant was $\mathrm{Zn}$. Murici seeds outstood by the great content of $\mathrm{P}$, whereas sweet passionfruit seeds, by the levels of $\mathrm{K}, \mathrm{Ca}$, and $\mathrm{Mg}$. Other Cerrado fruits also stood out due to their Ca content, such as macaúba (Acrocomia aculeata Mart) (130 mg/100g w.b.), chichá

Table 3. Mineral profile $(\mathrm{mg} / 100 \mathrm{~g})$ and mineral contribution to the Dietary Recommended Ingestion (DRI) of pequi almonds, murici, and sweet passiofruit seeds.

\begin{tabular}{|c|c|c|c|c|c|c|}
\hline \multirow{2}{*}{$\begin{array}{c}\text { Minor } \\
\text { elements }\end{array}$} & \multicolumn{2}{|c|}{ Pequi } & \multicolumn{2}{|c|}{ Murici } & \multicolumn{2}{|c|}{ Sweet passionfruit } \\
\hline & Mineral & DRI (\%) & Mineral & DRI (\%) & Mineral & DRI (\%) \\
\hline $\mathrm{P}$ & 1690 & 241 & 1170 & 167 & 270 & 39 \\
\hline K & 990 & 21 & 120 & 2.6 & 700 & 15 \\
\hline $\mathrm{Ca}$ & 180 & 18 & 2 & 0.217 & 190 & 19 \\
\hline $\mathrm{Mg}$ & 520 & 200 & 1.8 & 0.7 & 180 & 69 \\
\hline $\mathrm{S}$ & 220 & - & 1 & - & 150 & - \\
\hline $\mathrm{Na}$ & 3 & 0.1 & 2 & 0.1 & 2 & 0.1 \\
\hline \multicolumn{7}{|l|}{$\begin{array}{c}\text { Trace } \\
\text { elements }\end{array}$} \\
\hline $\mathrm{Mn}$ & 3 & 143 & NS & NS & 1.5 & 65 \\
\hline $\mathrm{Zn}$ & 11 & 154 & 0.9 & 12 & 3 & 48 \\
\hline $\mathrm{Fe}$ & 5 & 39 & 3 & 24 & 1.5 & 11 \\
\hline $\mathrm{Cu}$ & 3 & 288 & 0.6 & 66 & 2 & 179 \\
\hline
\end{tabular}

NS: Not significant. 
(Sterculia striata A. St. Hil. \& Naud) (116.7 mg/100 g w.b.), and murici (78 mg/100 g w.b.) (Reis Silva et al., 2008). Reis Silva et al. (2008) also found $0.6 \mathrm{mg} \mathrm{Zn/100} \mathrm{g} \mathrm{w.b.,} \mathrm{and} 1.3 \mathrm{mg} \mathrm{Fe} / 100 \mathrm{~g}$ w.b. in murici fruits from the Brazilian Midwest (Goiás); although these values are in wet basis, in this study, murici seeds presented lower $\mathrm{Zn}$ content $(0.9 \mathrm{mg} / 100 \mathrm{~g}$ d.b.), and much higher Fe content (3.3 $\mathrm{mg} / 100 \mathrm{~g} \mathrm{d.b}$.) than the pulp, as reported by the authors.

Considering the content of minerals found in pequi almond, murici, and passionfruit seeds, it was possible to verify how much these almonds and seeds can contribute to the Daily Recommended Intake (DRI) of minerals, for an adult, in grams per $100 \mathrm{~g}$ of seeds (Table 3) (Institute of Medicine, 1997, 2001).

$\mathrm{P}$ requirement has often been linked to the Ca requirement, allowing a Ca:P weight ratio of about 1 . A Population Reference Intake (PRI) of $550 \mathrm{mg} /$ day in adults is suggested by the Scientific Committee for Food (1993). It is possible to supply that intake need, by only taking $33 \mathrm{~g}$ of pequi almonds, and $47 \mathrm{~g}$ of murici seeds a day. $\mathrm{P}$ is an essential nutrient involved in many physiological processes, such as the cell's energy cycle, regulation of the whole body acid-base balance, and in the mineralisation of bones and teeth (Scientific Committee on Food, 2006).

$\mathrm{K}$ is an essential nutrient involved in fluid, acid and electrolyte balance and is required for normal cellular function (Scientific Committee on Food, 2006). DRI in Europe are in the order of 3.1-3.5 g/day (Scientific Committee for Food, 1993). The US have set an intake of $4.7 \mathrm{~g} /$ day (Food Nutritional Board, 2005). All the seeds are able to supply these daily intake of $\mathrm{K}$.

Ca must be ingested with the diet in sufficient amounts to allow for Ca deposition during bone growth and modeling and to compensate for obligatory intestinal, faecal, and dermal losses during the life-time. Tolerable Upper Intake Levels (UL) of $2500 \mathrm{mg} /$ day intake is suggested (Scientific Committee on Food, 2006). None of the seeds, on a $100 \mathrm{~g}$ basis, would be able to supply this Ca intake need. It would be necessary about $1.4 \mathrm{~kg}$ of pequi almonds, $115.2 \mathrm{~kg}$ of murici seeds, and $13 \mathrm{~kg}$ of sweet passionfruit seeds to satisfy the daily intake of this element.

The Scientific Committee for Food (1993) determined an acceptable range of $\mathrm{Mg}$ intake for adults of $150-500 \mathrm{mg} /$ day. While the Institute of Medicine (1997) suggests from 310 to $420 \mathrm{mg}$. An amount of $100 \mathrm{~g}$ of pequi almonds, and of sweet passionfruit seeds can supply that need.

No recommended intake was set as adequate for sulfur, which is available from dietary inorganic sulfate from water and foods, and from sources of organic sulfate, such as glutathione and the sulfur amino acids methionine and cysteine. Metabolic breakdown of the recommended intake for protein and sulfur amino acids should provide adequate inorganic sulfate for synthesis of required sulfur-containing compounds (Food Nutritional Board, 2005).

$\mathrm{Na}$ is present in biological systems as the main cation in the extracellular space, acting to maintain extracellular volume and plasma osmolality (Scientific Committee on Food, 2006). For Na, the acceptable range of intakes for adults established by the Scientific Committee for Food (1993) was 0.025 to $0.15 \mathrm{~mol} /$ day. Content of $\mathrm{Na}$ in the seeds was very low in relation to the required daily intake need. UL of $\mathrm{Zn}$ is $25 \mathrm{mg}$ /day (Scientific Committee on Food, 2006), which corresponds to over $200 \mathrm{~g}$ of pequi almonds to supply the intake need. The recommended Fe intake for a male adult has been estimated as between 8 and 10 mg a day (Institute of Medicine, 2001; Scientific Committee for Food, 1993). Pequi almonds were the one closest in meeting the recommended intake needs (about $150 \mathrm{~g}$ of pequi). Fe deficiency is associated with reduced function of an array of iron-dependent enzymes and proteins (Beard \& Dawson, 1997).

In the USA, it has been recommended that adult males and females should consume a dietary intake of $0.9 \mathrm{mg} \mathrm{Cu} /$ day (Institute of Medicine, 2001). An European Union PRI of $1.1 \mathrm{mg} \mathrm{Cu} /$ day for adults was established (Scientific Committee for Food, 1993). In the UK, a reference nutrient intake of $1.2 \mathrm{mg} /$ day has been set for adults (Department of Health, 1998). Studies have also shown that $\mathrm{Cu}$ is required for infant growth, host defence mechanisms, bone strength, red and white cell maturation, iron transport, cholesterol and glucose metabolism (Uauy et al., 1998).

The consumption of $100 \mathrm{~g}$ of pequi almonds supply the mineral need in relation to the DRI of $\mathrm{P}, \mathrm{Mg}, \mathrm{Cu}, \mathrm{Mn}$, and $\mathrm{Zn}$. And when compared to the other seeds, besides presenting a greater contribution to the DRI of these minerals, it is also the one that contributes most to the DRI of Fe and Na. Therefore, pequi almonds present great mineral prominence concerning its potential to contribute to the DRI of these elements. The abundance of different mineral elements in these fruits' seeds stands out when compared with the data available for different fruits that are economically cultivated (Universidade Estadual de Campinas, 2011). This circumstance had already been emphasized by Almeida \& Silva (1994), who reported that due to the fact that pequizeiro (pequi tree) is characteristic of low fertility soils, the mineral content in the fruits was unexpected leading to the hypothesis that this is a highly efficient plant on nutrient extraction from the soil (Oliveira et al., 2006; Santana \& Naves, 2003).

According to Melo et al. (2004), the mineral content variation suggest a diversity among the populations studied in each region considering that this diversity may be the result of environmental factors or heterogeneity among the populations. Vera et al. (2005) and Vera et al. (2007) have already emphasized this peculiarity concerning chemical and physical characteristics of the pequi fruit, such as mass, volume, lipid fraction, $\mathrm{pH}$, and visual aspect. Facts that could be also assembled to the variation of components found in murici and sweet passionfruit seeds.

\subsection{Bioactive compounds}

Table 4 shows the data obtained for the bioactive compounds of pequi almonds, murici, and sweet passionfruit seeds.

\section{Carotenoids}

There is little information on the carotenoid content present in the seeds from Cerrado in the specialized literature. These are compounds of relevance once they are associated with the prevention of oxidative processes (Lima et al., 2007), and with the reduction of the risk of developing non-communicable diseases (Ziegler, 1991), thus, worthy to be studied in such potential 
Table 4. Bioactive compounds (carotenoids, total phenolic, in vitro antioxidant activity, ans monomeric anthocyanins) of pequi almonds, murici, and sweet passiofruit seeds.

\begin{tabular}{lccc}
\hline \multicolumn{1}{c}{ Bioactive compound } & Pequi $^{\mathrm{a}}$ & Murici $^{\mathrm{a}}$ & $\begin{array}{c}\text { Sweet } \\
\text { passionfruit }^{\mathrm{a}}\end{array}$ \\
\hline Carotenoids (mg/100g) & $0.03 \pm 0.01^{\mathrm{b}}$ & $0.4 \pm 0.03^{\mathrm{b}}$ & $9 \pm 2^{\mathrm{a}}$ \\
TPC (mg GAE/100 g) & $211 \pm 6^{\mathrm{b}}$ & $404 \pm 12^{\mathrm{a}}$ & $216 \pm 14^{\mathrm{b}}$ \\
In vitro antioxidant activity (IP\%) & $87 \pm 2^{\mathrm{a}}$ & $83 \pm 1^{\mathrm{b}}$ & $60 \pm 1^{\mathrm{c}}$ \\
Anthocyanins (mg CYG/100 g) & $14 \pm 2^{\mathrm{a}}$ & $0.1 \pm 0.01^{\mathrm{b}}$ & $2 \pm 1^{\mathrm{b}}$ \\
\hline
\end{tabular}

Data are mean \pm standard deviation $(\mathrm{n}=3){ }^{\mathrm{acc}}$ Data followed by the same letter in a row do not differ statistically $(\mathrm{p}<0.05)$; GAE: Gallic acid equivalent; CYG: Cyanidin-3-glucoside.

fruits. About 700 naturally occurring carotenoids have been identified so far, and about $10 \%$ of them can be found in the human diet. Some dietary carotenoids, such as $\beta$-carotene, serve as an important source of vitamin $\mathrm{A}$, which is the major known function of carotenoids in humans (Scientific Committee on Food, 2006). The preformed vitamin A is only present in animal products (e.g. liver, eggs, milk products), thus, in countries where the intake of animal products is low, carotenoids have to meet (i.e. by $80 \%$ or more in Asia and Africa) the vitamin A requirements. Even in developed countries carotenoids usually contribute to vitamin A supply by more than 40\% (Woutersen et al., 1999). On the other hand, the roles of carotenoids in seed are less clear than in other tissues, but are emerging. Carotenoid production in the seed is important for abscisic acid production and seed dormancy (Maluf et al., 1997). Furthermore, carotenoids contribute to the antioxidant system in seeds, which functions to limit free radical-induced membrane deterioration and seed ageing (Calucci et al., 2004; Pinzino et al., 1999).

The greatest carotenoid content was found for passionfruit seeds. Pequi almonds and murici seeds presented similar $(\mathrm{p}<0.05)$ content of carotenoids and phenolic compounds as it can be observed in Table 4. These values are close to those of other seeds and almonds typical of Brazilian cerrado, such as baru almond (Dipteryx alata) (Santos et al., 2016), graviola seeds (Annona muricata) (Silva \& Jorge, 2014), and marolo seeds (Annona crassiflora) (Luzia \& Jorge, 2013). Lima et al. (2007) studied the carotenoid content in the almonds and pulp from pequi, and found $0.3 \mathrm{mg} / 100 \mathrm{~g}$ (d.b.), and $7.3 \mathrm{mg} / 100 \mathrm{~g}$ (d.b.), respectively. According to these data the carotenoid content of the almonds is much lower than the value found in the fruit pulp. Note that the carotenoid content found in pequi almonds by Lima et al. (2007) was about ten times higher in relation to the content found for the same material in this work.

Rufino et al. (2010) analyzed the carotenoid content of 18 non-traditional Brazilian fruits'pulps, and found total carotenoid content for murici of $1 \mathrm{mg} / 100 \mathrm{~g}$ (w.b.). Rodrigues et al. (2016) identified 35 carotenoid esters in murici fruit, being the most relevant, lutein, $\beta$-carotene, and violaxanthin.

Santana et al. (2015) determined the total carotenoid content of the oil of several passionfruit seeds species and reported a content of $115.4 \mathrm{mg} \beta$-carotene/100 $\mathrm{g}$ of oil for Passiflora setacea (BRS Pérola do Cerrado), value higher than that determined in this work. However, sweet passionfruit presented the highest content of carotenoids amongst the other fruits studied, meeting almost half of the minimum daily intake recommended by the European Food Safety Authority (20 mg $\beta$-carotene) (Scientific Committee on Food, 2006). A number of descriptive, cohort and case-control studies have been reviewed (International Agency for Research on Cancer, 1998; Woutersen et al. 1999), suggesting that carotenoid and/or $\beta$-carotene rich diets may prevent cardiovascular disease. Dietary carotenoids have been suggested to reduce the risk of age-related macular degeneration (Cooper et al., 1999; Seddon et al., 1994), the most common cause of irreversible blindness in people over age 65 in western European countries. A case-control study in Greece (Bohlke et al.,1999) involved 820 women with histologically confirmed breast cancer who were compared with 1548 control women. In conclusion, the general assumption is confirmed that individuals who eat more fruits and vegetables, rich in carotenoids, and/or have high levels of serum $\beta$-carotene, have a lower risk for cancer and cardiovascular diseases.

The low carotenoid content of many staple foods, such as cereals, can exacerbate dietary deficiencies. The World Health Organization (1996) has estimated that more than 100 million children are vitamin A-deficient and up to 500,000 of these children become blind each year. Many of these children die within 12 months of going blind. Thus, understanding the regulation of carotenoid accumulation in food crops, especially tubers and cereals, should facilitate improvements to nutritional value with potentially significant health benefits (Howitt \& Pogson, 2006).

\section{Total phenolic content}

Polyphenols display important functions, like inhibition of pathogens and decay microorganisms, anti-deposition of triglycerides, anti-inflammatory and anti-allergic effect through processes involving reactive oxygen species (Graf et al., 2005).

Total phenolic content (TPC) varied from 211 to $404 \mathrm{mg} \mathrm{GAE} / 100 \mathrm{~g}$ in the seeds. Pequi almonds and sweet passionfruit seeds were the materials with the lowest content and murici seeds with the greatest. Lima et al. (2007) reported $122 \mathrm{mg} \mathrm{GAE} / 100 \mathrm{~g}$ for pequi almonds, value $57 \%$ lower than that found in this study. Data on TPC of an array of Cerrado fruits are also available. Abadio Finco et al. (2012) evaluated the phenolic content of three different Cerrado fruits from the Midwest region of Brazil (Tocantins), including murici. The authors obtained $53.2 \mathrm{mg} \mathrm{GAE} / 100 \mathrm{~g}$ (w.b.), $32.3 \mathrm{mg} \mathrm{GAE} / 100 \mathrm{~g}$ (w.b.), and $298.3 \mathrm{mg} \mathrm{GAE} / 100 \mathrm{~g}$ (w.b.), for buriti (Mauricia flexuosa), cagaita (Eugenia dysenterica), and murici (Byrsonima crassifolia L. Rich), respectively. The total phenolic content found is consistent with data from the literature in relation to the other seeds from Cerrado fruits, once data on the same fruits studied here are scarce.

Lima et al. (2007) affirmed that the values of TPC for pequi seeds are higher than the ones usually found in most fruit pulps consumed in Brazil, based on studies by Kuskoski et al. (2005), on açaí (Euterpe oleracea) (136.8 mg GAE/100g), guava (83 mg GAE/100 g), soursop (Annona muricata L.) (84.3 mg GAE/100 g), pineapple (21.7 mg GAE/100 g), and passionfruit (20 mg GAE / $100 \mathrm{~g}$ ), only lower than the result 
obtained for acerola (Malpighia glabra) (580 mg GAE/ 100g), and mango (545 mg GAE/100g).

Aside with being responsible for the taste, flavor, and color of foods, one of the major polyphenol characteristics is the radicalscavenging capacity, which is involved in antioxidant properties, and the ability to interact with proteins. The high antioxidant capacity makes polyphenols an important key factor which is involved in the chemical defense of plants against pathogens and predators, and in plant-plant interferences (Dixon \& Paiva, 1995; Ozcan et al., 2014).

\section{In vitro antioxidant activity}

Lima et al. (2007) reported that pequi pulp has a high antioxidant potential due to the amount of total phenolics found in this part of the fruit (209 mg GAE/100g d.b.), since several authors have found a positive correlation between the amount of phenolics and the antioxidant activity. Thus, the seeds analyzed in this study (pequi, murici, and sweet passionfruit) can also be considered potential sources of antioxidants, considering the total phenolic values found for the three seeds. The antioxidant activities of pequi almonds, murici, and sweet passionfruit seeds, determined by the free $\cdot$ DPPH scavanging method varied from 60 to $87 \%$.

The capacity of the sample to scavange the free $\bullet \mathrm{DPPH}$ is considered strong when it reaches a percentage of $70 \%$, moderate when the values are between 50 and $70 \%$, and weak when it is below $50 \%$ (Melo et al., 2008). Thus, the respective seeds analyzed in this work have high (pequi and murici) and moderate (sweet passionfruit) capacity to scavange this free radical. Luzia \& Jorge (2014) reported antioxidant activity for soursop seeds of 76\%, 92\% for pitanga (Eugenia uniflora L.) seeds, and $95.9 \%$ for cagaita (Eugenia dysenterica DC) seeds. While, Luzia \& Jorge (2013) found $87.8 \%$ for marolo (Annona crassiflora Mart.) seeds.

Pequi is a fruit found in regions where the trees receive a high incidence of solar rays, which favors the generation of free radicals, in addition to which both the pulp and the almonds of pequi are rich in lipids (Table 4). These conditions favor the biosynthesis of secondary compounds with antioxidant properties (phenolic compounds and total carotenoids). These results indicate that pequi almonds, and also murici seeds are materials with high antioxidant capacity, demonstrating the correlation between total phenolics and antioxidant protection (Kuskoski et al., 2005).

\section{Monomeric anthocyanins}

Anthocyanins are water-soluble vacuolar pigments found in many plant tissues (Naczk \& Shahidi, 2006). Although most commonly accumulated in flowers and fruits, they are also present in leaves, stems, and storage organs (Rodríguez-Delgado et al., 2002), such as seeds.

In relation to these compounds, the highest value was found in pequi dry almonds, followed by sweet passionfruit, and murici seeds. Total anthocyanin content varies substantially across plant species and even cultivars (Wu et al., 2006). Available data show a very wide range of anthocyanin content in plant material with berries usually providing the most anthocyanins per serving. Environmental factors such as light, temperature, and altitude also affect anthocyanin concentration considerably (Naczk \& Shahidi, 2003).

When analyzing the anthocyanin content present in passionfruit and acerola seeds, both in dry matter, Ribeiro Silva et al. (2014) found values of $3.7 \mathrm{mg} / 100 \mathrm{~g}$, and $246 \mathrm{mg} / 100 \mathrm{~g}$, respectively. In the studies conducted by Sales \& Waughon (2013) no anthocyanins were detected in murici (bark + pulp). In the seeds of murici studied here, it is possible to affirm that only traces of these substances were found. Rufino et al. (2010) also analyzed this fruit and found $0.5 \mathrm{mg} / 100 \mathrm{~g}$ of anthocyanin in fresh matter.

Dietary anthocyanin sources include many colorful fruits and vegetables (He \& Giusti, 2010). With regard to mass consumed, anthocyanins constitute perhaps the most important subclass of flavonoids. Daily intake of anthocyanins had previously been estimated to be 180-215 mg per day per person (Kühnau, 1976), but according to a recent report by the USDA (U.S. Department of Agriculture), that evaluated more than 100 common foods, the estimation was $12.5 \mathrm{mg}$ per day per person in the United States (Wu et al., 2006). Pequi almonds are one of this materials that could supply this estimated average intake of anthocyanins.

\section{Conclusions}

Pequi almonds are important sources of lipids and proteins, which are the major components in their composition. Sweet passionfruit seeds have high fiber, lipid, and protein content. Murici seeds have high carbohydrate and fiber content and significant lipid fraction. Pequi almonds stood out for containing higher levels of all studied minerals when compared to sweet passionfruit seeds and murici, except for calcium, with a higher content in sweet passionfruit seed. Pequi almonds and murici seeds distinguished by the high content of phosphorus. The seed with the highest starch content was of murici, whereas the passionfruit seed was the richest in total and soluble pectin. Regarding bioactive compounds, pequi almonds were richer in anthocyanins, murici seeds presented higher total phenolic content and antioxidant activity, and sweet passionfruit seeds had the highest carotenoid values.

\section{References}

Abadio Finco, F. D. B., Silva, I. G., \& Oliveira, R. B. (2012). Physicochemical characteristics and antioxidant activity of three native fruits from Brazilian Savannah (Cerrado). Brazilian Journal of Food and Nutrition, 23(2), 179-185.

Almeida, S. P. (1998). Frutas nativas do cerrado: caracterização físico química e fonte potencial de nutrientes. In S. M. Sano \& S. P. Almeida (Eds.), Cerrado: ambiente e flora (pp. 247-285). Planaltina: EMBRAPA-CPAC.

Almeida, S. P., \& Silva, J. A. (1994). Piqui e Buriti: a importância alimentar para a população dos Cerrados. Planaltina: EMPRAPA-CPAC.

Alves, G. L., \& Franco, M. R. B. (2003). Headspace gas chromatographymass spectrometry of volatile compounds in murici (Byrsonima crassifolia L. Rich). Journal of Chromatography A, 985(1-2), 297-301. http://dx.doi.org/10.1016/S0021-9673(02)01398-5. PMid:12580497. 
Association of Official Analytical Chemists - AOAC. (2016). Official methods of analysis of the Association of Official Analytical Chemists International (20th ed.). Gaithersburg: AOAC.

Araújo, R. R., Santos, E. D., Lemos, E. E. P., \& Alves, R. E. (2009). Biometric characteristics of fruits and seeds of genotypes of muricy (Byrsonima verbascifolia (L.) Rich.) of the coastal tray of Alagoas. Revista Caatinga, 22(3), 220-224.

Baker, R. A. (1997). Reassessment of some fruit and vegetable pectin levels. Journal of Food Science, 62(2), 225-229. http://dx.doi. org/10.1111/j.1365-2621.1997.tb03973.x.

Beard, J. L., \& Dawson, H. D. (1997). Iron. In B. L. O’Dell \& R. A. Sunde (Eds.), Handbook of nutritionally essential mineral elements (pp. 275-334). New York: Marcel Dekker.

Bitter, T., \& Muir, H. M. (1962). A modified uronic acid carbazole reaction. Analytical Biochemistry, 4(4), 330-334. http://dx.doi. org/10.1016/0003-2697(62)90095-7. PMid:13971270.

Bohlke, K., Spiegelman, D., Trichopoulou, A., Katsouyanni, K., \& Trichopoulos, D. (1999). Vitamins A, C and E and the risk of breast cancer: results from a case-control study in Greece. British Journal of Cancer, 79(1), 23-29. http://dx.doi.org/10.1038/sj.bjc.6690006. PMid:10408688.

Braga, M. F., Santos, E. C., Junqueira, N. T. V., Sousa, A. A. T. C., Faleiro, F. G., Rezende, L. N., \& Junqueira, K. P. (2006). Cutting rooting of three wild Passiflora species. Revista Brasileira de Fruticultura, 28(2), 284-288.

Brand-Williams, W., Cuvelier, M. E., \& Berset, C. (1995). Use of a free radical method to evaluate antioxidant activity. LebensmittelWissenschaft + Technologie, 28(1), 25-30. http://dx.doi.org/10.1016/ S0023-6438(95)80008-5.

Calucci, L., Capocchi, A., Galleschi, L., Ghiringhelli, S., Pinzino, C., Saviozzi, F., \& Zandomeneghi, M. (2004). Antioxidants, free radicals, storage proteins, puroindolines, and proteolytic activities in bread wheat (Triticum aestivum) seeds during accelerated aging. Journal of Agricultural and Food Chemistry, 52(13), 4274-4281. http://dx.doi. org/10.1021/jf0353741. PMid:15212480.

Caramori, S. S., Lima, C. S., \& Fernandes, K. F. (2004). Biochemical characterization of selected plant species from Brazilian savannas. Brazilian Archives of Biology and Technology, 47(2), 253-259. http:// dx.doi.org/10.1590/S1516-89132004000200013.

Carrazza, L. R., \& Ávila, J. C. C. (2010). Aproveitamento integral do fruto do pequi. Brasília: ISPN.

Carvalho, L. M. J., Gomes, P. B., Godoy, R. L. O., Pacheco, S., Monte, P. H. F., Carvalho, J. L. V., Nutti, M. R., Neves, A. C. L., Vieira, A. C. R. A., \& Ramos, S. R. R. (2012). Total carotenoid content, $\alpha$-carotene and $\beta$-carotene, of landrace pumpkins (Cucurbita moschata Duch): A preliminary study. Food Research International, 47(2), 337-340. http://dx.doi.org/10.1016/j.foodres.2011.07.040.

Cavalcanti, M. L. F. (1989). Dietary fibers. Revista de Nutrição Da PUCCAMP, 2(1), 88-97.

Chitarra, M. I. F., \& Chitarra, A. B. (2005). Pós-colheita de frutos e hortaliças: fisiologia e manuseio (2. ed.). Lavras: UFLA.

Colombo, N. B. R., Rangel, M. P., Martins, V., Hage, M., Gelain, D. P., Barbeiro, D. F., Grisolia, C. K., Parra, E. R., \& Capelozzi, V. L. (2015). Caryocar brasiliense Camb protects against genomic and oxidative damage in urethane-induced lung carcinogenesis. Brazilian Journal of Medical and Biological Research, 48(9), 852-862. http://dx.doi. org/10.1590/1414-431X20154467. PMid:26200231.

Cooper, D. A., Eldridge, A. L., \& Peters, J. C. (1999). Dietary carotenoids and certain cancers, heart disease, and age-related macular degeneration: a review of recent research. Nutrition Reviews, 57(7), 201-214. http:// dx.doi.org/10.1111/j.1753-4887.1999.tb06944.x. PMid:10453174.

Costa, G. V., Regis, S., Magalhães, A., \& Galvão, M. I. (2013, Novembro 10-15). Caracterização histoquímica dos compostos de reserva da semente de Byrsonima sp. In $64^{\circ}$ Congresso Nacional de Botânica, Belo Horizonte: Sociedade Botânica do Brasil.

Darnet, S. H., Silva, L. H. M., Rodrigues, A. M. C., \& Lins, R. T. (2011). Nutritional composition, fatty acid and tocopherol contents of buriti (Mauritia flexuosa) and patada (Oenocarpus batata) fruit pulp from the amazon region. Food Science and Technology, 31(2), 488-491. http://dx.doi.org/10.1590/S0101-20612011000200032.

Department of Health. (1998). Nutritional aspects of the development of cancer. Report of the working group on diet and cancer of the Committee on Medical Aspects of Food and Nutrition Policy. Reports on Health and Social Subjects, 48, 1-274. PMid:9599404.

Dixon, R. A., \& Paiva, N. L. (1995). Stress-induced phenylpropanoid metabolism. The Plant Cell, 7(7), 1085-1097. http://dx.doi.org/10.1105/ tpc.7.7.1085. PMid:12242399.

Fernandes, D. C., Freitas, J. B., Czeder, L. P., \& Naves, M. M. V. (2010). Nutritional composition and protein value of the baru (Dipteryx alara Vog.) almond from the Brazilian Savanna. Journal of the Science of Food and Agriculture, 90(10), 1650-1655. http://dx.doi. org/10.1002/jsfa.3997. PMid:20564449.

Figueiredo, P. R. L., Oliveira, I. B., Santana, J. B. No, Oliveira, J. A., Ribeiro, L. B., Barros Viana, G. S., Rocha, T. M., Leal, L. K. A. M., Kerntopf, M. R., Felipe, C. F. B., Coutinho, H. D. M., \& Alencar Menezes, I. R. (2016). Caryocar coriaceum Wittm. (pequi) fixed oil presents hypolipemic and anti-inflammatory effects in vivo and in vitro. Journal of Ethnopharmacology, 191, 87-94. http://dx.doi. org/10.1016/j.jep.2016.06.038. PMid:27321275.

Food and Agriculture Organization of the United Nations. (2003). Food energy: Methods of analysis and conversion factors. Rome: FAO. 87 p.

Food Nutritional Board. (2005). Dietary Reference Intakes for water, potassium, sodium, chloride, and sulfate. Washington, D.C.: The National Academies Press.

Graf, B. A., Milbury, P. E., \& Blumberg, J. B. (2005). Flavonols, flavones, flavanones, and human health: Epidemiological evidence. Journal of Medicinal Food, 8(3), 281-290. http://dx.doi.org/10.1089/ jmf.2005.8.281. PMid:16176136.

Guimarães, M. M., \& Silva, M. S. (2008). Nutritional value and chemical and physical characteristics of dried murici fruits (Byrsonima verbascifolia). Food Science and Technology (Campinas), 28(4), 817-821.

Gunstone, F. D. (2005). Vegetable oils. In F. Shahidi (Ed.), Bailey's industrial oil \& fat products (6th ed.). New York: John Wiley \& Sons. http://dx.doi.org/10.1002/047167849X.bio018.

He, J., \& Giusti, M. M. (2010). Anthocyanins: natural colorants with health-promoting properties. Annual Review of Food Science and Technology, 1(1), 163-187. http://dx.doi.org/10.1146/annurev. food.080708.100754. PMid:22129334.

Howitt, C. A., \& Pogson, B. J. (2006). Carotenoid accumulation and function in seeds and non-green tissues. Plant, Cell \& Environment, 29(3), 435-445. http://dx.doi.org/10.1111/j.1365-3040.2005.01492.x. PMid:17080597.

International Agency for Research on Cancer - IARC. (1998). Handbooks of cancer prevention meetings (Vol. 2). Lyon: IARC.

Institute of Medicine (1997). Standing committee on the scientific evaluation of dietary reference intakes. Dietary reference intakes for calcium, phosphorus, magnesium, vitamin D, and fluoride. Washington: National Academies Press. 
Institute of Medicine (2001). Panel on micronutrients. Dietary Reference Intakes for vitamin $A$, vitamin $K$, arsenic, boron, chromium, copper, iodine, iron, manganese, molybdenum, nickel, silicon, vanadium, and zinc. Washington: National Academies Press.

Kelsay, J. L. (1978). A review of research on effects of fiber intake on man. The American Journal of Clinical Nutrition, 31(1), 142-159. http://dx.doi.org/10.1093/ajcn/31.1.142. PMid:413425.

Kühnau, J. (1976). The flavonoids: a class of semi-essential food components: their role in human nutrition. World Review of Nutrition and Dietetics, 24, 117-191.

Kuskoski, E. M., Asuero, A. G., Troncoso, A. M., Mancini, J. Fo, \& Fett, R. (2005). Aplicación de diversos métodos químicos para determinar actividad antioxidante en pulpa de frutos. Food Science and Technology, 25(4), 726-732. http://dx.doi.org/10.1590/S010120612005000400016.

Lima, A., Silva, A. M. O., Trindade, R. A., Torres, R. P. P., \& ManciniFilho, J. (2007). Chemical composition and bioactive compounds in the pulp and almond of pequi fruit. Revista Brasileira de Fruticultura, 29(3), 695-698. http://dx.doi.org/10.1590/S0100-29452007000300052.

Lima, L. B., Lima, I. V. M., \& Silva, M. G. V. (2006, Setembro 25-29). Estudo do potencial proteico, lipídico e antioxidante de resíduos de frutos de indústrias do estado do Ceará. In 46 Congresso Brasileiro de Química, Salvador: Associação Brasileira de Química.

Luzia, D. M. M., \& Jorge, N. (2013). Bioactive substance contents and antioxidant capacity of the lipid fraction of Annona crassiflora Mart. seeds. Industrial Crops and Products, 42, 231-235. http://dx.doi. org/10.1016/j.indcrop.2012.05.027.

Luzia, D. M. M., \& Jorge, N. (2014). Study of antioxidant activity of non-conventional Brazilian fruits. Journal of Food Science and Technology, 51(6), 1167-1172. http://dx.doi.org/10.1007/s13197011-0603-x. PMid:24876651.

Maluf, M. P., Saab, I. N., Wurtzel, E. T., \& Sachs, M. M. (1997). The viviparous 12 maize mutant is deficient in abscisic acid, carotenoids, and chlorophyll synthesis. Journal of Experimental Botany, 48(311), 1259-1268. http://dx.doi.org/10.1093/jxb/48.6.1259.

Mariano da Silva, S., Brait, J. D. A., Faria, F. P., Silva, S. M., Oliveira, S. L., Braga, P. F., \& Mariano da Silva, F. M. S. (2009). Chemical characteristics of pequi fruits (Caryocar brasiliense Camb.) native of three municipalities in the State of Goiás - Brazil. Food Science and Technology (Campinas), 29(4), 771-777. http://dx.doi.org/10.1590/ S0101-20612009000400011.

Mattos, L. L., \& Martins, I. S. (2000). Deitary fiber consumption in an adult. Journal of Public Health, 34(1), 50-55. PMid:10769361.

Matuda, T. G., \& Maria Netto, F. (2005). Partial chemical characterization of jatobá-do-cerrado seeds (Hymenaea stigonocarpa Mart.). Food Science and Technology, 25(2), 353-357. http://dx.doi.org/10.1590/ S0101-20612005000200029.

McCready, R. M., \& McComb, E. A. (1952). Extraction and determination of total pectic materials in fruits. Analytical Chemistry, 24(12), 1586-1588. http://dx.doi.org/10.1021/ac60072a033.

Melo, A. F. Jr, Carvalho, D., Póvoa, J. S. R., \& Bearzoti, E. (2004). Genetic structure of natural populations of pequizeiro (Caryocar brasiliense Camb.). Scientia Forestalis, (66), 55-65.

Melo, E. A., Maciel, M. I. S., Lima, V. L. A. G., \& Nascimento, R. S. (2008). Antioxidant capacity of the fruits. Brazilian Journal of Pharmaceutical Sciences, 44(2), 193-201.

Merril, A. L., \& Watt, B. K. (1973). Energy value of foods: basis and derivation. Washington: United States Department of Agriculture.

Monteiro, D. C. B., Sousa, W. C., Pires, C. R. F., Azevedo, L. A., \& Borges, J. S. (2015). Physical and chemical characterization of the fruit and jelly of murici (Brysonima crassifolia). Enciclopédia Biosfera, 11(21), 3356-3366.

Moreno Luzia, D. M., \& Jorge, N. (2011). Evaluating of the activity antioxidant and fatty acids profile of lychee seeds (Litchi chinensis SONN.). Nutrition \& Food Science, 41(4), 261-267. http://dx.doi. org/10.1108/00346651111151393.

Naczk, M., \& Shahidi, F. (2003). Contribution of phenolic compounds to flavor and color characteristics of foods. In F. Shahidi \& M. Naczk (Eds.), Phenolics in Food and Nutraceuticals (pp. 443-461). Boca Raton: CRC Press. http://dx.doi.org/10.1201/9780203508732.ch9.

Naczk, M., \& Shahidi, F. (2006). Phenolics in cereals, fruits and vegetables: occurrence, extraction and analysis. Journal of Pharmaceutical and Biomedical Analysis, 41(5), 1523-1542. http://dx.doi.org/10.1016/j. jpba.2006.04.002. PMid:16753277.

National Research Counsil. (1989). Recommended dietary allowances (10th ed.). Washington: National Academies Press.

Neida, S., \& Elba, S. (2007). Characterization of the acai or mancada (Euterpe oleracea Mart.): a fruit of the Amazon. Archivos Latinoamericanos de Nutricion, 57(1), 94-98. PMid:17824205.

Nelson, N. A. (1944). A photometric adaptation of Somogyi method for the determination of glucose. The Journal of Biological Chemistry, 153, 375-380.

Oliveira, J. C., \& Ruggiero, C. (2005). Espécies de maracujá com potencial agronômico. In F. G. Faleiro, N. T. V Junqueira \& M. F. Braga (Ed.), Maracujá: Germoplasma e melhoramento genético. Planaltina: Embrapa Cerrados.

Oliveira Sousa, A. G., Fernandes, D. C., Alves, A. M., Freitas, J. B., \& Naves, M. M. V. (2011). Nutritional quality and protein value of exotic almonds and nut from the Brazilian Savanna compared to peanut. Food Research International, 44(7), 2319-2325. http://dx.doi. org/10.1016/j.foodres.2011.02.013.

Oliveira, M. L. M., Nunes-Pinheiro, D. C. S., Tomé, A. R., Mota, É. F., Lima-Verde, I. A., Pinheiro, F. G. M., Campello, C. C., \& Morais, S. M. (2010). In vivo topical anti-inflammatory and wound healing activities of the fixed oil of Cariocar coriaceum Wittm. seeds. Journal of Ethnopharmacology, 129(2), 214-219. http://dx.doi.org/10.1016/j. jep.2010.03.014. PMid:20332017.

Oliveira, M. N. S., Gusmão, E., Lopes, P. S. N., Simões, M. O. M., Ribeiro, L. M., \& Dias, B. A. S. (2006). Maturity stage of fruis and factors related to nutritive and texture characters of pequi (Caryocar brasiliense Camb.). Revista Brasileira de Fruticultura, 28(3), 380-386. http://dx.doi.org/10.1590/S0100-29452006000300010.

Oliveira, R. C., Barros, S. T. D., \& Gimenes, M. L. (2013). The extraction of passion fruit oil with green solvents. Journal of Food Engineering, 117(4), 458-463. http://dx.doi.org/10.1016/j.jfoodeng.2012.12.004.

Ozcan, T., Akpinar-Bayizit, A., Yilmaz-Ersan, L., \& Delikanli, B. (2014). Phenolics in human health. International Journal of Chemical Engineering and Applications, 5(5), 393-396. http://dx.doi.org/10.7763/ IJCEA.2014.V5.416.

Pinzino, C., Capocchi, A., Galleschi, L., Saviozzi, F., Nanni, B., \& Zandomeneghi, M. (1999). Aging, free radicals, and antioxidants in wheat seeds. Journal of Agricultural and Food Chemistry, 47(4), 1333-1339. http://dx.doi.org/10.1021/jf980876d. PMid:10563976.

Ramadan, M. F., Asker, M. M. S., \& Tadros, M. (2012). Antiradical and antimicrobial properties of cold-pressed black cumin and cumin oils. European Food Research and Technology, 234(5), 833-844. http:// dx.doi.org/10.1007/s00217-012-1696-9.

Ratter, J. A., Ribeiro, J. R., \& Bridgewater, S. (1997). The Brazilian cerrado vegetation and threats to its biodiversity. Annals of Botany, 80(3), 223-230. http://dx.doi.org/10.1006/anbo.1997.0469. 
Reis Silva, M., Lacerda, D. B. C. L., Santos, G. G., \& Martins, D. M. O. (2008). Chemical characterization of native species of fruits from Savanna ecosystem. Ciência Rural, 38(6). http://dx.doi.org/10.1590/ S0103-84782008000600051.

Rezende, C. M., \& Fraga, S. R. (2003). Chemical and aroma determination of the pulp and seeds of murici (Byrsonima crassifolia L.). Journal of the Brazilian Chemical Society, 14(3), 425-428. http://dx.doi. org/10.1590/S0103-50532003000300014.

Roberts, E. H. (1973). Predicting the storage life of seeds. Seed Science and Technology, 1, 499-514.

Rodrigues, D. B., Mariutti, L. R. B., \& Mercadante, A. Z. (2016). Two-step cleanup procedure for the identification of carotenoid esters by liquid chromatography-atmospheric pressure chemical ionization-tandem mass spectrometry. Journal of Chromatography. A, 1457, 116-124. http://dx.doi.org/10.1016/j.chroma.2016.06.039. PMid:27371019.

Rodríguez-Carpena, J.-G., Morcuende, D., Andrade, M.-J., Kylli, P., \& Estévez, M. (2011). Avocado (Persea americana Mill.) phenolics, in vitro antioxidant and antimicrobial activities, and inhibition of lipid and protein oxidation in porcine patties. Journal of Agricultural and Food Chemistry, 59(10), 5625-5635. http://dx.doi.org/10.1021/ jf1048832. PMid:21480593.

Rodríguez-Delgado, M. A., González, G., Pérez-Trujillo, J. P., \& García-Montelongo, F. J. (2002). Trans-resveratrol in wines from the Canary Islands (Spain). Analysis by high performance liquid chromatography. Food Chemistry, 76(3), 371-375. http://dx.doi. org/10.1016/S0308-8146(01)00258-8.

Roesler, R., Catharino, R. R., Malta, L. G., Eberlin, M. N., \& Pastore, G. (2010). Antioxidant activity of Caryocar brasiliense (pequi) and characterization of components by electrospray ionization mass spectrometry. Food Chemistry, 110(3), 711-717.

Rufino, M. S. M., Alves, R. E., Brito, E. S., Pérez-Jiménez, J., SauraCalixto, F., \& Mancini, J. Fo (2010). Bioactive compounds and antioxidant capacities of 18 non-traditional tropical fruits from Brazil. Food Chemistry, 121(4), 996-1002. http://dx.doi.org/10.1016/j. foodchem.2010.01.037.

Sales, A., \& Waughon, T. G. M. (2013). Influence of processing on the bioactive compound content in murici and hog plum fruits. Agrarian, 6(19), 7-15.

Salinas, Y. G., \& Garcia, R. (1985). Métodos químicos para el análisis de suelos acidos y plantas forrajeras. Colômbia: Centro Internacional de Agricultura Tropical.

Santana, F. C., Shinagawa, F. B., Araujo, E. S., Costa, A. M., \& Mancini, J. Fo (2015). Chemical composition and antioxidant capacity of Brazilian Passiflora seed oils. Journal of Food Science, 80(12), C2647-C2654. http://dx.doi.org/10.1111/1750-3841.13102. PMid:26512548.

Santana, J. C., \& Naves, R. V. (2003). Characterization of cerrado areas with high pequizeiro (Caryocar brasiliense Camb.) density in the Southeast of the state of Goiás. Revista Agropecuária Tropical, 33(1), 1-10.

Santos, P., Aguiar, A. C., Viganó, J., Boeing, J. S., Visentainer, J. V., \& Martínez, J. (2016). Supercritical $\mathrm{CO}_{2}$ extraction of cumbaru oil (Dipteryx alata Vogel) assisted by ultrasound: Global yield, kinetics and fatty acid composition. The Journal of Supercritical Fluids, 107, 75-83. http://dx.doi.org/10.1016/j.supflu.2015.08.018.

Scientific Committee for Food. (1993). Reports of the SCF (31st series): nutrient and energy intakes for the European Community. Luxembourg: Commission of the European Communities.

Scientific Committee on Food. (2006). Tolerable upper intake levels for vitamins and minerals. Belgium: European Food Safety Authority.
Seddon, J. M., Ajani, U. A., Sperduto, R. D., Hiller, R., Blair, N., Burton, T. C., Farber, M. D., Gragoudas, E. S., Haller, J., Miller, D. T. (1994). Dietary carotenoids, vitamins A, C, and E, and advanced age-related macular degeneration. Eye disease case-control study group. Journal of the American Medical Association, 272(18), 1413-1420. http:// dx.doi.org/10.1001/jama.1994.03520180037032. PMid:7933422.

Silva, A. C., \& Jorge, N. (2014). Bioactive compounds of the lipid fractions of agro-industrial waste. Food Research International, 66, 493-500. http://dx.doi.org/10.1016/j.foodres.2014.10.025.

Silva, L. M. R., Figueiredo, E. A. T., Ricardo, N. M. P. S., Vieira, I. G. P., Figueiredo, R. W., Brasil, I. M., \& Gomes, C. L. (2014). Quantification of bioactive compounds in pulps and by-products of tropical fruits from Brazil. Food Chemistry, 143, 398-404. http://dx.doi.org/10.1016/j. foodchem.2013.08.001. PMid:24054258.

Siqueira, E. M. A., Rosa, F. R., Fustinoni, A. M., Sant’Ana, L. P., \& Arruda, S. F. (2013). Brazilian Savanna fruits contain higher bioactive compounds content and higher antioxidant activity relative to the conventional red delicious apple. PLoS One, 8(8), 1-7. http://dx.doi. org/10.1371/journal.pone.0072826. PMid:23991156.

Souza, V. R., Pereira, P. A. P., Queiroz, F., Borges, S. V., \& Carneiro, J. D. S. (2012). Determination of bioactive compounds, antioxidant activity and chemical composition of Cerrado Brazilian fruits. Food Chemistry, 134(1), 381-386. http://dx.doi.org/10.1016/j. foodchem.2012.02.191.

StatSoft, Inc. (2007). Statistica: data analysis software system. Version 8.0. Tulsa: StatSoft, Inc.

Torres, L. R. O., Shinagawa, F. B., Santana, F. C., Araújo, E. S., Oropeza, M. V. C., Macedo, L. F. L., Almeida-Muradian, L. B., Lima, H. C., \& Mancini-Filho, J. (2016). Physicochemical and antioxidant properties of the pequi (Cariocar brasiliense Camb.) almond oil obtained by handmade and cold-pressed processes. International Food Research Journal, 23(4), 1541-1551.

Uauy, R., Olivares, M., \& Gonzalez, M. (1998). Essentiality of copper in humans. The American Journal of Clinical Nutrition, 67 (5, Suppl), 952S-959S. http://dx.doi.org/10.1093/ajcn/67.5.952S. PMid:9587135.

Universidade Estadual de Campinas - UNICAMP. (2011). Brazilian Table of Food Composition: TACO (4th ed.). Campinas: UNICAMP/NEPA.

Vera, R., Naves, R. V., Nascimento, J. L., Chaves, L. J., Leandro, W. M., \& Souza, E. R. B. (2005). Physical characterization of pequi fruits (Caryocar brasiliense Camb.) in Goiás state. Pesquisa Agropecuária Tropical, 35(2), 72-79.

Vera, R., Souza, E. R. B., Ferandes, E. P., Naves, R. V., Soares, M. S. Jr., Caliari, M., \& Ximenes, P. A. (2007). Physical and chemical characteristics of pequi (Caryocar brasiliense Camb.) fruits from two ares in Goiás state, Brazil. Pesquisa Agropecuária Tropical, 37(2), 93-99.

Vilas Boas, E. V. B. (2004, Maio 25-28) Frutas minimamente processadas: pequi. In $3^{\circ}$ Encontro Nacional Sobre Processamento Mínimo de Frutas e Hortaliças (pp. 122-127). Viçosa: Universidade Federal de Viçosa.

Waterhouse, A. L. (2002). Wine phenolics. Annals of the New York Academy of Sciences, 957(1), 21-36. http://dx.doi.org/10.1111/j.1749-6632.2002. tb02903.x. PMid:12074959.

Woutersen, R. A., Wolterbeek, A. P. M., Appel, M. J., van den Berg, H., Goldbohm, R. A., \& Feron, V. J. (1999). Safety evaluation of synthetic $\beta$-Carotene. Critical Reviews in Toxicology, 29(6), 515-542. http:// dx.doi.org/10.1080/10408449991349267. PMid:10628775.

World Health Organization - WHO. (1996). Indicators for assessing vitamin A deficiency and their application in monitoring and evaluating intervention programs. Geneva: WHO. 
World Health Organization - WHO. (2012). Sodium intake for adults and children. Geneva: WHO.

Wrolstad, R. E. (1993). Color and pigment analyses in fruit products (pp. 1-17, Station Bulletin, No. 624). Oregon State University: Agricultural Experiment Station.

Wu, X., Beecher, G. R., Holden, J. M., Haytowitz, D. B., Gebhardt, S. E., \& Prior, R. L. (2006). Concentrations of anthocyanins in common foods in the United States and estimation of normal consumption.
Journal of Agricultural and Food Chemistry, 54(11), 4069-4075. http://dx.doi.org/10.1021/jf0603001. PMid:16719536.

Yu, L., Haley, S., Perret, J., \& Harris, M. (2002). Antioxidant properties of hard winter wheat extracts. Food Chemistry, 78(4), 457-461. http:// dx.doi.org/10.1016/S0308-8146(02)00156-5.

Ziegler, R. G. (1991). Vegetables, fruits, and carotenoids and the risk of cancer. The American Journal of Clinical Nutrition, 53(1, Suppl), 251S-259S. http://dx.doi.org/10.1093/ajcn/53.1.251S. PMid:1985395. 